\title{
Can We Afford It? The association between financial aid and time to completion in Accounting Higher Education in South Africa: A literature review
}

\author{
Riley Carpenter \\ Lily Roos \\ College of Accounting, University of Cape Town, South Africa
}

\section{Key Words}

Academic performance, accounting students, financial aid, higher education, South Africa, time to completion

\begin{abstract}
Internationally, research has been conducted on factors affecting students' academic success as measured by time to degree completion. Investigating these factors is important given the role of higher education in the South African context. Astin's Input-Environment-Outcome (I-E-O) model was used to analyse the factors affecting students' academic success. These included key input and environmental factors identified in prior literature such as race, gender, prior academic results, English proficiency, high school quality, family income, first-generation educational status, integration into higher education institutions, student employment and financial aid. To date, South African research on financial aid has concentrated on how financial aid improves access to higher education, however, there is very little information on how it effects on-time degree completion. This paper thus identifies a gap in the role of financial aid in assisting timely graduation and examines this phenomenon in relation to accountancy students in South Africa.
\end{abstract}

\section{Introduction}

South Africa has made significant strides in tertiary education in recent years, notably the increase in student attendance at university, particularly amongst Black South Africans (South African Institute of Race Relations, 2019). However, it has been found that Black students were more likely to be academically excluded earlier in their degree programmes, and graduated at slower rates than their White peers (Neethling, 2015). Race is being used to provide historical context to describe and measure the effects of current policies and practices redressing the inequities of the past (Department of Higher Education and Training [DHET], 2014). DHET (2014) uses the composite term 'Black' to refer to the racial descriptors of African, Coloured, and Indian/Asian. These racial descriptors, with White, are used for planning, monitoring, and funding purposes.

Access to university is not sufficient; students also need to graduate in order to be classified as academically successful. Understanding student success is a complicated exercise, reflecting the multifaceted nature of this phenomenon (Granito and Santana, 2016; Morris, 2016). It is nonetheless essential that institutions understand the factors that influence students' ability to graduate on time.

Since the advent of democracy to South Africa in 1994, higher education institutions (HEI) have been tasked with equalising access to HEIs and improving the quality of academic success based on changes in the social and demographic profile of the student population (DHET, 2015). Despite the challenges faced by the higher education sector, HEIs saw exceptional growth in Black South African student enrolments (Council on Higher Education [CHE], 2016). However, there has not been a corresponding increase in student success, as measured by timely graduation (DHET, 2016).

The vision for HEIs in South Africa is to increase throughput, graduation and participation rates (CHE, 2013; DHET, 2014). Recent research indicates that undergraduate students in South Africa have high dropout and low graduation rates and their degrees take longer than prescribed to complete (Cloete, 2016; CHE, 2016; DHET, 2015; van Broekhuizen, van der Berg and Hofmeyr, 2016). HEIs must therefore gain insight into the factors that effect on-time graduation to effectively support students (Cloete, 2016; CHE, 2016; Universities South Africa, 2016). 
Although the national undergraduate graduation rate is low, the University of Cape Town (UCT) reported an improvement in its undergraduate graduation rates. In the 2016 Teaching and Learning Report (UCT, 2017), UCT reported to DHET that the institution exceeded its targeted cohort completion rates set in 2011 for all undergraduate programmes. The University recognised that there were wideranging factors that led to this improvement and that these needed further investigation, particularly with regard to the experiences of Black students and the impediments to their success (UCT, 2017).

There are multiple factors at play in understanding student success. Similarly, there are many variables that impact degree completion. These include race, gender, high school grade point average (GPA), mathematics mark, science mark, English proficiency, high school quality, family income, firstgeneration educational status, integration into HEI systems, student employment and financial aid.

Through a qualitative analysis of literature, this paper establishes the role of financial aid amongst the factors that impact degree completion in South Africa.

The following research questions are addressed in this paper:

1. Why is it important to understand what affects students' academic success?

2. How can the key variables for student success be categorised?

3. What are the factors affecting students' academic success?

4. What is the impact of financial aid on students' academic success in South Africa, as reported in the literature?

This paper begins by contextualising the research topic within the theoretical framework of Astin's Input-Environment-Outcome model, explaining the impact of the input and environmental variables on degree completion. The paper then homes in on more specific factors that could affect students' completion of their degree, focusing specifically on financial aid.

\section{Methodology}

An online search of the Google Scholar and UCT library databases was conducted. All papers and published reports on variables impacting degree completion were identified. The abstracts of the studies were then scrutinised to determine whether they would be relevant to this paper. The selected literature was then evaluated in terms of the four research questions of the paper, within a refined 15-year time period of 2005 to 2019 to take into account recent trends and shifts within Accounting Education and new challenges faced by students.

\section{Literature review}

\subsection{Importance of understanding what affects students' academic success}

Over the past few decades, HEIs have increasingly focused on improving the rate at which students graduate from universities. As a result, studies have investigated factors either facilitating or preventing students' on-time degree completion. This has been achieved by measuring various student outcomes and selected aspects of academic success (Astin, 1984; DHET, 2016; Theune, 2015; Tinto, 1975; Zewotir, North and Murray, 2011). However, the cognitive and non-cognitive processes of learning and development are complex. Similarly, measuring academic success can be challenging as factors such as students' attitudes, strategies, skills and behaviours cannot be gauged through grading, scores and standardised testing (Fook and Sidhu, 2015; York, Gibson and Rankin, 2015).

Most commonly, researchers have measured academic success in terms of students' educational achievements such as those who achieved or exceeded a specified grade or GPA (Letkiewicz et al., 2014; Treviño, Scheele and Flores, 2014; Yue and Fu, 2017), credit accumulation (Denning, 2017; Donhardt, 2013), degree completion (Arendt, 2013; Murray, 2014) or time to completion (Letkiewicz et al., 2014; Yue and $\mathrm{Fu}, 2017)$. Measuring student outcomes, however, cannot fully inform us why some students succeed and others, with similar characteristics, drop out (Murray, 2014) or 'stop out' (interrupt enrolment) from higher education (DesJardins and McCall, 2010). In attempts to develop a more holistic approach, studies have included not only student outcomes but also students' development and integration into the university's social and academic environment such as student engagement (Zumbrunn, McKim, Buhs and Hawley, 2014) or institutional culture (Lewin and Mawoyo, 2014).

Improving graduation rates and on-time graduation is a focal point for HEIs in South Africa (CHE, 2010, 2016; DHET, 2016) where on-time graduation means that full-time equivalent (FTE) students 
manage to graduate within the designated timeframe for their programme (that is, completing a threeyear bachelor degree in three years or a four-year bachelor degree in four years). Isolating the factors which lead to academic success at university is crucial as it would identify students who require additional support as well as assisting HEIs to develop the right programmes to help those students.

\subsection{Astin's Input-Environment-Outcome (I-E-O) model}

Multiple factors could affect students' academic success in a particular degree. Astin's InputEnvironment-Outcome (I-E-O) model simplifies the complexity of higher education research by examining the interdependence of inputs, environments and outputs (Astin, 1984). The original purpose of the model was to examine the impact of environmental variables on outcomes, accounting for background characteristics (Astin, 1993). The I-E-O model allows researchers to examine multiple effects simultaneously, which helps to avoid the problem of a lack of random assignment.

\subsection{Student input characteristics}

Tinto (1975) contends that students' personal attributes affect their academic success. Students' involvement in university life and academic development is influenced by these attributes as well as their overall satisfaction with student-faculty interaction (Zhou and Cole, 2017).

Several international studies have examined the association between degree completion and factors such as race and gender (Kim and Sax, 2009), high school GPA (Letkiewicz et al., 2014), English proficiency (Dooley, Payne and Robb, 2012), family income (Scott-Clayton, 2015), first-generation educational status (Wohlgemuth et al., 2007) and financial support (Chen and DesJardins, 2010). In addition, mathematics and science marks (Zewotir et al., 2011) as well as high school quality (van Broekhuizen et al., 2016) contribute to the impact on degree completion in South Africa.

\subsubsection{Race and gender}

The differential effect of race and gender on student outcomes has been widely explored in the literature (Bhorat, Goga and Stanwix, 2014; Gross, Torres and Zerquera, 2013; Kim, 2004; Kim and Sax, 2014; Schreiber and Yu, 2016). The effect of financial aid can be moderated by race and ethnicity (Gross, Torres and Zerquera, 2013). Kim and Sax (2009) investigated the effects of financial aid on the attainment of underrepresented students in Indiana. The study found that the frequency of student-faculty interaction varied across student race and gender for undergraduate students at the University of California, which affected their outcomes.

Research on education in South Africa includes race and gender as critical variables for student outcomes (Bhorat and Pillay, 2017; Murray, 2014; Schreiber and Yu, 2016; Wangenge-Ouma, 2012; Zewotir et al., 2011). This is understandable as HEIs are tasked with redressing the inequalities of the past and providing previously disadvantaged students, especially black and female students, with reasonable and equitable opportunities for academic success (DHET, 2016; Universities South Africa, 2015).

DHET (2016) report that African female participation has increased steadily over the past few years, all females have had lower dropout rates than males and have the best chance of graduating on time. The demographic profile of higher education in South Africa has changed progressively since democracy, and much of the targeted growth in Black and female student representation has been achieved (Universities South Africa, 2015). However, the low graduation and throughput rates have overshadowed this growth and continue to reflect apartheid era patterns concerning race (DHET, 2016). The UCT 2017 Teaching and Learning Report (2018) indicates that the graduate profile differed markedly between Black and White students, suggesting that there is still work to be done to close the performance gap between these two groups.

\subsubsection{Previous academic results}

A vast amount of research has been performed on past academic results affecting student outcomes, both internationally and in South Africa. Past accounting research on student performance has explored the effect of either aggregate high school results, high school mathematics results, high school English results, high school accounting results or a combination of these on academic performance (AidooBuameh and Ayagre, 2013; Gul and Fong, 1993; Jansen and De Villiers, 2016; McKenzie and Schweitzer, 2001; Papageorgiou, 2017; Papageorgiou and Carpenter, 2019; Pullen, Toerien and Anthony, 2015). 
Positive relationships were found between the various high school results and academic performance at university.

\subsubsection{Type of school}

There is very little research on the type of school attended by students and its impact on university performance. Unfortunately, the two Australian studies (Evans and Farley, 1998; Jackling and Anderson, 1998) on this topic are contradictory and therefore provide limited evidence.

Secondary education in South Africa comprises private schools, schools previously classified as Model C schools and government or public schools. These classifications depend on the level of government funding (Tikley and Mabogoane, 1997), with Model C schools receiving part private and part government funding. While South Africa spends a high proportion of gross domestic product (GDP) and taxation on education, this is not reflected in public school students' performance in their graduation results (South African Institute of Race Relations, 2018). Pullen et al. (2015) and Jansen and de Villiers (2016) found limited evidence of school type impacting student outcomes.

The Department of Basic Education divides South African schools into five quintiles to determine the level of school subsidy that a particular school is entitled to. Schools in the first quintile are the poorest while the $20 \%$ of schools that are the most well off are in the fifth quintile (Roodt, 2018). Private or independent schools and former Model C schools would generally be classified in the higher quintiles compared to government or public schools.

In the 2016 South African Grade 12 national results, students from wealthy schools (which include public and private schools) contributed the vast majority of passes above $80 \%$ for mathematics (Roodt, 2018). As mathematics is a potential predictor of tertiary education performance, these results are worrying. Additionally, high school results are a good indicator of university access, but a limited contributor to outcome (van Broekhuizen et al., 2016).

\subsection{Institutional environment}

Astin (1993) emphasises that understanding the educational process and factors that influence academic success will be limited with input from students only; information about the environment in which the students are studying must also be taken into consideration. Student integration into university is complex and while universities cannot mitigate all the factors inhibiting students' academic success, they must pay serious attention to the known factors to assist students' transition to university life and facilitate social and academic integration.

\subsubsection{Language of instruction}

The language of instruction is seen as a significant hurdle to academic success (van Rooy and Coetzee-van Rooy, 2015). South Africa has 11 official languages, and with English as the medium of instruction in most HEIs in South Africa, this is likely to influence academic success for those students who have English as a second or third language (Baard, Steenkamp, Frick and Kidd, 2010).

The lack of English proficiency, both written and verbal, poses a barrier to social and academic integration for most Black South African students (Lewin and Mawoyo, 2014). This challenge is not limited to black South Africans only but, also to the White Afrikaans-speaking student body (Baard et al., 2010). The lack of English proficiency limits the students' ability to interact with faculty staff and lecturers, it makes it difficult to take useful notes and results in students falling behind as the workload increases (Dukhan, Cameron and Brenner, 2016; van Rooy and Coetzee-van Rooy, 2015). When students enrolled for both English literacy modules as well as critical thinking workshops, they had a better chance of academic success (Dukhan et al., 2016).

South African research on language and performance has been contradictory. In accountancy, the performance of Black students has been significantly affected by race and home language (Sartorius and Sartorius, 2013). When these students were instructed in their home language, their results improved (Baard et al., 2010), however, in some cases, this was not statistically significant (du Plessis, Muller and Prinsloo, 2005; Jansen and De Villiers, 2016) while in others, it was. 


\subsubsection{Integration into the academic and social systems of HEIs}

Tinto $(1975,1982)$ contends that there is a connection between students' integration into the academic and social systems of the institution and their persistence in completing their degree, or alternately, dropping out. Astin (1993) postulates that student success is influenced by the attributes the student brings to institution and its environment.

Student-faculty interaction, across gender and racial subgroups, is crucial in student development, whether in the classroom or in other venues such as laboratories (Kim and Sax, 2009). Zumbrunn et al. (2014) suggest that student perceptions of the classroom as well as academic and social support may consequently affect their motivation, engagement, and academic achievement.

Broadbridge and Swanson (2006) explored how employment affected students' social life while at university. Some of the participants indicated that it was difficult to manage their workloads, and as a result, missed lectures with less time to study. Others associated working while studying with a sacrifice of social time at university but had a positive outcome for the social aspects of working.

\subsection{Financial aid}

Internationally, many studies on students' academic success and on-time graduation have examined the role that finances play in persistence after students enrol in university.

\subsubsection{Fees and on-time graduation}

Tuition-free education, though desirable, may slow down on-time graduation as students who are not sensitive to the cost associated with higher education may consume more of the funding, adding more years to degree completion (Lang, Chan, Pask-Aube and Swift, 2009). While high tuition fees may hinder access to higher education (Pennell and West, 2005), in certain instances, it was found that high fees did, in fact, improve on-time degree completion (Bruckmeier, Fischer and Wigger, 2015; Garibaldi, Giavazzi, Ichino and Rettore, 2012).

Raised tuition fees

Garibaldi et al. (2012) investigated the effect of raised tuition fees after the prescribed period for graduation and discovered that students who expected an increase in tuition fees after the fourth year of study made a more concerted effort to finish their studies on time. Additionally, the reduced probability of late graduation did not have an adverse effect on the dropout rate or on the quality of student performance (Garibaldi et al., 2012). Bruckmeier et al. (2015) studied the effect of the introduction of tuition fees at previously fee-free institutions and concluded that the introduction of fees did not significantly affect students' enrolments although it did improve the time-to-completion.

\section{Cost-sharing model}

Higher education in South Africa is not 'free' but highly subsidised by the government (Bhorat and Pillay, 2017; Oketch, 2016). It functions on a cost-sharing model consisting mainly of state subsidies and tuition fees (Universities South Africa, 2016; Wangenge-Ouma, 2012). Despite the decline in state funding, DHET (2014) encouraged HEIs to set tuition fees at a level that would give students - especially those from poor and middle-class families - access to higher education and help them to complete their degree on time. Despite this request, research on tuition fees shows that the cost of higher education has risen steeply in recent decades (Boatman and Long, 2016; Cloete, 2016; Pennell and West, 2005; WangengeOuma, 2012).

Rising education costs

In South Africa, from 2015 to 2018, students protested against high tuition fees and the lack of financial assistance (Dominguez-Whitehead, 2017). These protests reflected the effects of increasing costs of higher education coupled with declining employment opportunities (Mngomezulu, Dhunpath and Munro, 2017). The rising costs of education, together with the cost of living, make it more difficult for students to afford higher education. Students who cannot afford the costs of higher education enter the labour market while studying out of necessity, as an alternative to stopping out (DesJardins and McCall, 2010; Soria, Weiner and Lu, 2014) or dropping out (Chen, 2012). While student employment in itself is not a problem, it may prolong time to degree completion. 


\subsubsection{Student employment and time to graduation}

Students facing financial difficulties and how they divide their time between work and study has been the subject of many studies (Beerkens, Mägi and Lill, 2011; Bozick, 2007; Dundes and Marx, 2007; Hogan, Bryant and Overymyer-Day, 2013; Lerma-Gardia, 2017; Neill, 2015; Triventi, 2014). One would think that students who do not work would devote more time to their studies and would therefore complete their degree on time as opposed to those who have to juggle academic and work life. However, research has found that employment may be beneficial for academic success depending on the number of hours and the reason(s) students elect to work (Astin, 1984; Beerkens et al., 2011; Darolia, 2014; Dundes and Marx, 2007; Hogan et al., 2013; Neill, 2015). The reasons students gave for working were to pay for living expenses (Dundes and Marx, 2007; Triventi, 2014), to pay for tuition fees (Dundes and Marx, 2007; Neill, 2015) and career advancement (Beerkens et al., 2011; Wenz and Yu, 2010; Yanbarisova, 2014).

Advantages and disadvantages of student employment

International research on the effect of student employment on time-to-degree suggests that students benefit from working limited hours (Bozick, 2007; Dwyer, McCloud and Hodson, 2012; Hogan et al., 2013; Wenz and $\mathrm{Yu}, 2010)$. Students who opt to work while studying may increase their chances of success as it may improve their soft skills such as time efficiency, problem-solving and personal responsibility (Dundes and Marx, 2007). Dundes and Marx (2007) further reveal that a limited amount of employment (10-19 hours in their study) provides a significant improvement in GPA.

These findings have been corroborated by other international studies. Wenz and Yu (2010) discovered that students who worked limited hours and whose employment developed career-specific skills earned higher GPA scores than those who worked excessively and for other reasons. Similarly, Darolia (2014) found a positive relationship between students' academic grades and working up to five hours. Beerkens et al. (2011) observed no significant effect on the students' academic progression for students who worked for less than 25 hours per week. On the other hand, Triventi (2014) found a negative relationship between academic progression and students who experienced financial constraints and worked an average of 35 hours per week (high intensity).

High tuition fees and student employment

Triventi (2014) found a positive relationship between the level of tuition fees and the likelihood of students working while studying at universities. A study by Neill (2015) found that the response to high tuition fees differed amongst students depending on their living arrangements and parental education. The researcher found that the rise in tuition fees in Canada seemed to have resulted in a corresponding rise in student employment.

The effect of working on academic progression may vary depending on the number of hours worked, and the reason the student elects to work (Triventi, 2014). In South Africa, students from low socioeconomic groups who experience food and housing insecurity may increase their hours of work (Broton and Goldrick-Rab, 2017; Dominguez-Whitehead, 2015, 2017) which in turn may impede their academic success. Moreover, students from impoverished backgrounds who receive financial assistance are sometimes expected to redirect some of this funding to support their families (Mngomezulu et al., 2017). Working students who receive additional financial aid may lower their hours of work, which in turn will improve their academic success and time to completion.

\subsubsection{Financial aid and time to graduation}

Numerous international studies have investigated the impact of financial aid as a factor that may improve time to degree completion (Chen and Hossler, 2017; Chen and DesJardins, 2010; Oketch, 2016; Yue and $\mathrm{Fu}, 2017)$.

The purpose of financial aid

Financial aid reduces the cost of higher education and promotes academic success (Dwyer et al., 2012; Dynarski, 2016; Goldrick-Rab, 2016; Scott-Clayton, 2015). Students may receive financial aid from their families, private companies, philanthropic organisations, or government, based on a variety of conditions. Financial aid could be awarded based on merit, whether academic or athletic (Chen and DesJardins, 2010; Cohodes and Goodman, 2014; Sjoquist and Winters, 2015), on financial need (Stater, 
2009) or to improve access, persistence and academic success (Bhorat and Pillay, 2017; Bird and Castleman, 2016; DesJardins and McCall, 2010). Sufficient financial resources are seen as a contributing factor for students to engage both academically and socially (Jones, Coetzee and Bailey, 2008).

Consequently, the availability of financial aid has become increasingly more important for students from socially and economically disadvantaged backgrounds. While the purpose of financial aid is to lower the cost of education, South African research on the effect of financial aid has concentrated on how it improves access rather than how it contributes to on-time degree completion.

Level of financial aid

In the United States of America (USA), Chen and DesJardins (2010) concluded that merit and needbased aid improved persistence and academic success and that greater financial assistance to minority groups resulted in a significant increase in persistence and decreased dropout risk. They found that a variety of factors such as age, family income, parental education and financial aid influenced students' dropout rates.

After controlling for sex, race, ethnicity, high school attended and SAT (originally the Scholastic Aptitude Test) scores in the USA, Sjoquist and Winters (2015) found no significant difference in degree completion between pre- and post-merit award recipients. Their results imply that merit aid had no meaningful effect on college attendance or degree completion. Merit aid generally does not cover full tuition fees but may increase access and reduce the potential need to work while at university (Cohodes and Goodman, 2014). One can draw similarities between the low-income and minority groups in the USA and Black South African students concerning low graduation rates. Therefore, it could be inferred that greater financial assistance, along with affordable tuition to disadvantaged groups, would have the same effect in improving on-time graduation.

The National Student Financial Aid Scheme (NSFAS)

In South Africa, the National Student Financial Aid Scheme (NSFAS) manages and directs financial aid to students who are not able to afford university education (CHE, 2016). Bhorat and Pillay (2017) investigated the performance of NSFAS beneficiaries for the period 2000 to 2012 by demographics and subject pass rates. Using the subject pass rate as an indicator of performance, the researchers found a positive relationship between the award size and the subject pass rate. This relationship, in turn, suggests that higher NSFAS awards might enable students to perform better at HEIs. However, the NSFAS data were not compared with the Higher Education Management Information System (HEMIS) data to examine dropout or graduation rates. This link is essential to determine the impact of financial aid on student dropout risk and degree completion.

\section{Conclusion}

This paper examined the importance of understanding the factors affecting students' academic success, specifically time to degree completion. Insights on this topic are vital as they would help to identify students who require additional support as well as assisting universities to devise appropriate strategies to help those students. Using Astin's Input-Environment-Outcome (I-E-O) model, it became clear that many factors affect degree completion. These include race, gender, prior academic results, English proficiency, high school quality, family income, first-generation educational status, integration into HEIs, student employment and financial aid.

To date, South African research on financial aid has concentrated on how financial aid improves access to higher education, however, there is very little information on how it effects on-time degree completion. Even though South Africa has a history of disparities in its education system, the higher education sector has seen growth in Black student enrolments. Unfortunately, this has not resulted in a corresponding increase in on-time graduation. Further research into financial aid would create a better understanding of how such support could assist timely graduation.

\section{Limitations and direction for future research}

The scope of the paper is limited to a review of literature. Future research should empirically study the factors identified that significantly affect on-time degree completion, specifically in South Africa. 


\section{References}

Aidoo-Buameh, J., \& Ayagre, P. (2013). The effect of entry grades on academic performance of university accounting students: A case of undergraduates of Central University College. Research Journal of Finance and Accounting, 4(7), 198-206.

Arendt, J. N. (2013). The effect of public financial aid on dropout from and completion of university education: Evidence from a student grant reform. Empirical Economics, 44(3), 1545-1562.

Astin, A. W. (1984). Student involvement: A developmental theory for higher education. Journal of College Student Development, 40, 518-529.

Astin, A. W. (1993). Assessment for excellence: The philosophy and practice of assessment and evaluation in higher education. New York: Oryx Press.

Baard, R. S., Steenkamp, L. P., Frick, B. L., \& Kidd, M. (2010). Factors influencing success in first-year Accounting at a South African university: The profile of a successful first-year Accounting student. South African Journal of Accounting Research, 24(1), 129-147.

Beerkens, M., Mägi, E., \& Lill, L. (2011). University studies as a side job: Causes and consequences of massive student employment in Estonia. Higher Education, 61(6), 679-692.

Bhorat, H., Goga, S., \& Stanwix, B. (2014). Skills-biased labour demand and the pursuit of inclusive growth in South Africa. WIDER Working Paper 2014/130. Helsinki: UNI-WIDER.

Bhorat, H., \& Pillay, N. (2017). The National Student Financial Aid Scheme (NSFAS) and the development of the higher education system in South Africa. Pretoria.

Bird, K., \& Castleman, B. L. (2016). Here today, gone tomorrow? Investigating rates and patterns of financial aid renewal among college freshmen. Research in Higher Education, 57(4), 395-422.

Boatman, A., \& Long, B. T. (2016). Does financial aid impact college student engagement? Evidence from the Gates Millennium Scholars Program. Research in Higher Education, 57(6), 653-681.

Bozick, R. (2007). Making it through the first year of college: The role of students' economic resources, employment and living arrangements. Sociology of Education, 80, 261-285.

Broadbridge, A., \& Swanson, V. (2006). Managing two roles. Community, Work \& Family, 9(2), 159-179.

Broton, K., \& Goldrick-Rab, S. (2017). The dark side of college (un)affordability: Food and housing insecurity in higher education. College Teaching and Learning for Change: Students and Faculty Speak Out, 1383(May), 151-163.

Bruckmeier, K., Fischer, G.-B., \& Wigger, B. U. (2015). Tuition fees and the time to graduation: Evidence from a natural experiment. Journal of Higher Education Policy and Management, 37(4), 459-471.

Chen, J., \& Hossler, D. (2017). The effects of financial aid on college success of two-year beginning non-traditional students. Research in Higher Education, 58(1), 40-76.

Chen, R. (2012). Institutional characteristics and college student dropout risks: A multilevel event history analysis. Research in Higher Education, 53(5), 487-505.

Chen, R., \& DesJardins, S. L. (2010). Investigating the impact of financial aid on student dropout risks: Racial and ethnic differences. The Journal of Higher Education, 81(2), 179-208.

Cloete, N. (2016). For sustainable funding and fees, the undergraduate system in South Africa must be restructured. South African Journal of Science, 112(3-4), 1-5.

Cohodes, S. R., \& Goodman, J. S. (2014). Merit aid, college quality and college completion: Massachusetts' Adams Scholarship as an in-kind subsidy. American Economic Journal: Applied Economics, 6(4), 251-285.

Council on Higher Education. (2010). Access and throughput in South African higher education: Three case studies. In Higher Education Monitor. Pretoria.

Council on Higher Education. (2013). The aims of higher education. Pretoria.

Council on Higher Education. (2016). South African higher education reviewed; Two decades of Democracy. Pretoria.

Darolia, R. (2014). Working (and studying) day and night: Heterogeneous effects of working on the academic performance of full-time and part-time students. Economics of Education Review, 38, 38-50.

Denning, J. T. (2017). Born under a lucky star: Financial aid, college completion, labor Supply and credit constraints. In Upjohn Institute working paper ; 17-267. DOI:https:/ / doi.org/10.17848/wp17-267

Department of Higher Education and Training. (2014). Report of the Ministerial Committee for the Review of the Funding of Universities. Pretoria.

Department of Higher Education and Training. (2015). Statistics on Post-School Education and Training in South Africa: 2013. Pretoria.

Department of Higher Education and Training. (2016). Report on the Second National Higher Education Transformation Summit. Durban.

DesJardins, S., \& McCall, B. (2010). Simulating the Effects of Financial Aid Packages on College Student Stopout, Reenrollment Spells, and Graduation Chances. The Review of Higher Education, 33(4), 513-541.

Dominguez-Whitehead, Y. (2015). Students' food acquisition struggles in the context of South Africa: The fundamentals of student development. Journal of College Student Development, 56(3 PG-292-308), 292-308. 
Dominguez-Whitehead, Y. (2017). Food and housing challenges : (Re)framing exclusion in higher education. Journal of Education, 1(68), 149-169.

Donhardt, G. L. (2013). The Fourth-Year Experience: Impediments to Degree Completion. Innovative Higher Education, 38(3), 207-221.

Dooley, M. D., Payne, A. A., \& Robb, A. L. (2012). Persistence and academic success in university. Canadian Public Policy, 38(3), 315-339.

du Plessis, A., Muller, H., \& Prinsloo, P. (2005). Determining the profile of the successful first-year accounting student. South African Journal of Higher Education, 19(4), 684-698.

Dukhan, S., Cameron, A., \& Brenner, E. (2016). Impact of mother tongue on construction of notes and first-year academic performance. South African Journal of Science, 112(11/12), 1-6.

Dundes, L., \& Marx, J. (2007). Balancing Work and Academics in College: Why Do Students Working 10 To 19 Hours Per Week Excel? Journal of College Student Retention, 8(1), 107-120.

Dwyer, R. E., McCloud, L., \& Hodson, R. (2012). Debt and Graduation from American Universities. Social Forces, 90(4), 1133-1155.

Dynarski, S. M. (2016). American Economic Association Does Aid Matter? Measuring the Effect of Student Aid on College Attendance and Completion. The American Economic Review, 93(1), 279-288.

Evans, M., \& Farley, A. (1998). Institutional characteristics and the relationship between students' first-year university and final-year secondary school academic performance. The Journal of Institutional Research in Australia, 7(2), 3644.

Fook, C. Y., \& Sidhu, G. K. (2015). Investigating Learning Challenges Faced by Students in Higher Education. Procedia - Social and Behavioral Sciences, 186, 604-612. Elsevier B.V.

Garibaldi, P., Giavazzi, F., Ichino, A., \& Rettore, E. (2012). College Cost and Time to Complete a Degree: Evidence from Tuition Discontinuities. Review of Economics and Statistics, 94(3), 699-711.

Goldrick-Rab, S. (2016). Reducing Income Inequality in Educational Attainment. Experimental Evidence on the Impact of Financial Aid on College Completion. American Journal of Sociology, 121(6), 1762-1817.

Granito, V., \& Santana, M. (2016). Psychology of Learning Spaces: Impact on Teaching and Learning. Journal of Learning Spaces, 5(1), 1-8.

Gross, J. P. K., Torres, V., \& Zerquera, D. (2013). Financial Aid and Attainment Among Students in a State with Changing Demographics. Research in Higher Education, 54(4), 383-406.

Gul, F. A., \& Fong, S. C. C. (1993). Predicting success for introductory accounting students: some further Hong Kong evidence. Accounting Education, 2(1), 33-42. DOI:10.1080/09639289300000003

Hogan, E. A., Bryant, S. K., \& Overymyer-Day, L. E. (2013). Relationships between College Students' Credit Card Debt, Undesirable Academic Behaviors and Cognitions, and Academic Performance. College Student Journal, 47(1), 102-112.

Jackling, B., \& Anderson, A. (1998). Study mode, general ability and performance in accounting: a research note. Accounting Education, 7(1), 65-73. DOI:10.1080/096392898331315

Jansen, \& De Villiers, C. (2016). Determinants of student performance in an accounting degree programme. South African Journal of Accounting Research, 30(1), 1-28. DOI:10.1080/10291954.2015.1019223

Jones, B., Coetzee, G., \& Bailey, T. (2008). Factors that facilitate success for disadvantaged higher education students. Cape Town.

Kim, D. (2004). The effect of financial aid on students' college choice: Differences by racial groups. Research in Higher Education, 45(1), 43-70.

Kim, Y., \& Sax, L. (2009). Student-faculty interaction in research universities: Differences by student gender, race, social class, and first-generation status. Research in Higher Education, 50(5), 437-459.

Kim, Y., \& Sax, L. (2014). The effects of student-faculty interaction on academic self-concept: Does academic major matter? Research in Higher Education, 55, 780-809.

Lang, D., Chan, H., Pask-Aube, C., \& Swift, K. (2009). Does the Level of Tuition Fees Affect Student Retention and Graduation? Canadian Society for the Study of Higher Education Annual Conference, 1-33. Ottawa.

Lerma-Gardia, T. D. (2017). Working Experience: Maximising the Federal Work-Study (FWS). California State University, Sacramento.

Letkiewicz, J., Lim, H., Heckman, S., Bartholomae, S., Fox, J. J., \& Montalto, C. P. (2014). The Path to Graduation: Factors Predicting On-Time Graduation Rates. Journal of College Student Retention: Research, Theory \& Practice, 16(3), 351-371.

Lewin, T., \& Mawoyo, M. (2014). Student Access and Success: Issues and Interventions in South African Universities. In The South African Institute for Advancement. Cape Town.

McKenzie, K., \& Schweitzer, R. (2001). Who Succeeds at University? Factors predicting academic performance in first year Australian university students. Higher Education Research \& Development, 20(1), 21-33. DOI:10.1080/07924360120043621 
Mngomezulu, S., Dhunpath, R., \& Munro, N. (2017). Does financial assistance undermine academic success? Experiences of 'at risk' students in a South African university. Journal of Education, (68), 131-148.

Morris, L. V. (2016). Mining Data for Student Success. Innovative Higher Education, 41(3), 183-185.

Murray, M. (2014). Factors affecting graduation and student dropout rates at the University of KwaZulu-Natal. South African Journal of Science, 110(11-12), 1-6.

Neethling, L. (2015). The determinants of academic outcomes: A competing risks approach. Proceedings of the 2015 Conference of the Economic Society of South Africa, 1-17. Cape Town.

Neill, C. (2015). Rising student employment: the role of tuition fees. Education Economics, 23(1), 101-121.

Oketch, M. (2016). Financing higher education in sub-Saharan Africa: some reflections and implications for sustainable development. Higher Education, 72(4), 525-539.

Papageorgiou, E. (2017). Accounting students' profile versus academic performance: A five-year analysis. South African Journal of Higher Education, 31(3), 31-33. DOI:10.20853/31-3-1064

Papageorgiou, E., \& Carpenter, R. (2019). Prior accounting knowledge of first-year students at two South African universities: Contributing factor to academic performance or not? South African Journal of Higher Education, 33(6), 249-264. DOI:https://doi.org/10.20853/33-6-3032

Pennell, H., \& West, A. (2005). The impact of increased fees on participation in higher education in England. Higher Education Quarterly, 59(127-137), 127-137.

Pullen, E., Toerien, F., \& Anthony, J. (2015). Student Endogenous Factors that Impact on Performance in Advanced Management Accounting: an Exploratory Study. Proceedings of the 2015 SAAA/IAAER Biennial Conference, 604621.

Roodt, M. (2018). The South African Education Crisis: Giving Power back to parents (The South African Institute of Race Relations Report May 2018). Johannesburg, South Africa.

Sartorius, K., \& Sartorius, B. (2013). The comparative performance of chartered accountancy students in South Africa: The impact of historical legacies. Development Southern Africa, 30(3), 401-416. DOI:10.1080/0376835X.2013.817307

Schreiber, B., \& Yu, D. (2016). Exploring student engagement practices at a South African university: Student engagement as reliable predictor of academic performance. South African Journal of Higher Education, 30(5), 157175.

Scott-Clayton, J. (2015). The Role of Financial Aid in Promoting College Access and Success: Research Evidence and Proposals for Reform. Journal of Student Financial Aid, 45(3, SI), 7-22.

Sjoquist, D. L., \& Winters, J. V. (2015). State merit-based financial aid programs and college attainment. Journal of Regional Science, 55(3), 364-390.

Soria, K. M., Weiner, B., \& Lu, E. C. (2014). Decisions Among Undergraduate Students from Low-Income and Working-Class Social Class Backgrounds. Journal of Student Financial Aid, 44(1), 1-23.

Stater, M. (2009). The Impact of Financial Aid on College GPA at Three Flagship Public Institutions. American Educational Research Journal, 46(3), 782-815.

The South African Institute of Race Relations. (2018). Achievement and enterprise in school education (The South African Institute of Race Relations Report May 2018).

The South African Institute of Race Relations. (2019). Free Facts: South Africa - a qualified success (The South African Institute of Race Relations Free Facts report No 3/2019 Issue 11).

Theune, K. (2015). The working status of students and time to degree at German universities. Higher Education, 70(4), $725-752$.

Tikley, L., \& Mabogoane, T. (1997). Marketisation as a strategy for desegregation and redress: The case of historically white schools in South Africa. International Review of Education, 43(2/3), 159-178.

Tinto, V. (1975). Dropout from Higher Education: A Theoretical Synthesis of Recent Research. Review of Educational Research, 45(1), 89-125.

Tinto, V. (1982). Limits of Theory and Practice in Student Attrition. The Journal of Higher Education, 53(6), 687-700.

Treviño, E., Scheele, J., \& Flores, S. M. (2014). Beyond the Test Score: A Mixed Methods Analysis of a College Access Intervention in Chile. Journal of Mixed Methods Research, 8(3), 255-265.

Triventi, M. (2014). Does working during higher education affect students' academic progression? Economics of Education Review, 41, 1-13.

Universities South Africa. (2015). Reflections on higher education transformation. Transforming Higher Education for a Transformed South Africa in a 21st Century World: A Call to Action. Durban.

Universities South Africa. (2016). Universities Funding in South Africa: A Fact Sheet. Pretoria.

University of Cape Town. (2017). 2016 Teaching and Learning Report. Cape Town.

University of Cape Town. (2018). 2017 Teaching and Learning Report. Cape Town.

van Broekhuizen, H., van der Berg, S., \& Hofmeyr, H. (2016). Higher Education Access and Outcomes for the 2008 National Matric Cohort. Stellenbosch Economic Working Papers, 16(16), 1-104. 
van Rooy, B., \& Coetzee-Van Rooy, S. (2015). The language issue and academic performance at a South African University. Southern African Linguistics and Applied Language Studies, 33(1), 31-46.

Wangenge-Ouma, G. (2012). Tuition fees and the challenge of making higher education a popular commodity in South Africa. Higher Education, 64(6), 831-844.

Wenz, M., \& Yu, W.-C. (2010). Term-Time Employment and the Academic Performance of Undergraduates. Journal of Education Finance, 35(4), 358-373.

Wohlgemuth, D., Whalen, D., Sullivan, J., Nading, C., Mack, S., \& Yongyi, W. (2007). Financial, academic, and environmental influences on the retention and graduation of students. Journal of College Student Retention, 8(4), $457-475$.

Yanbarisova, D. M. (2014). Combining University Studies With Work: Influence on Academic Achievement. Higher School of Economics Research Paper No. WP BRP 21/EDU/2014. DOI:http://dx.doi.org/10.2139/ssrn.2535776

York, T. T., Gibson, C., \& Rankin, S. (2015). Defining and Measuring Academic Success. Practical Assessment, Research \& Evaluation, 20(5), 1-20.

Yue, H., \& Fu, X. (2017). Rethinking Graduation and Time to Degree: A Fresh Perspective. Research in Higher Education, 58(2), 184-213.

Zewotir, T., North, D., \& Murray, M. (2011). Student Success in Entry Level Modules at the University of KwazuluNatal. South African Journal of Higher Education, 25(6), 1232-1243.

Zhou, J., \& Cole, D. (2017). Comparing international and American students: involvement in college life and overall satisfaction. Higher Education, 73(5), 655-672.

Zumbrunn, S., McKim, C., Buhs, E., \& Hawley, L. R. (2014). Support, belonging, motivation, and engagement in the college classroom: A mixed method study. Instructional Science, 42, 661-684. 